\title{
DEMOCRACY, PUBLIC EQUALITY AND THE MODERN STATE: REPLIES TO BACCARINI, CEROVAC, IVANKOVIĆ, MLADENOVIĆ, PRIJIĆ- SAMARŽIJA AND ZELIĆ
}

\section{Thomas Christiano}

Department of Philosophy

DOI: 10.20901/an.12.07

University of Arizona

E-mail: thomasc@email.arizona.edu

Diskusija

Primljeno: travanj 2016.

I am deeply honored by the papers in this symposium. The authors have all devoted an enormous amount of energy and care to thinking about many of the ideas I have written about over the last twenty or so years. I am extremely grateful and humbled by their attention to my work. I have also found every paper to be deeply illuminating; in some cases, I have found myself rethinking my positions; in other cases, I see areas which demand more attention than I have given up to now; in yet other cases I have acquired a deeper appreciation for the challenges that my views and arguments face. In each case, I learned a great deal both from the papers and the discussions about earlier drafts of these papers that took place at a conference on Equality and Citizenship at the University of Rijeka on July 1 and 2, 2014.
The following remarks are an attempt to summarize some main parts of the arguments I have given while responding to or taking into account the criticisms of the authors in this symposium. I have focused on areas in which the authors have expressed disagreement with my previous positions and have attempted to respond to them as best I can. I don't think I have responded to every good criticism made of my work and I am sure I have not done full justice to all the criticisms. In a sense, the following remarks should be understood as a contribution to an ongoing dialogue about the foundations and proper structure of a democratic regime. I have organized the papers and my responses in three groups: the first concerns my arguments about the foundations of democracy in public equality; the second con- 
cerns my discussion of two distinct versions of the broadly political liberal approach to political philosophy; the third concerns my efforts to think about the ideals of democracy in the context of the modern state and its political division of labor.

\section{Democracy as Grounded in Public Equality}

Ivan Cerovac's careful discussion of my position on the nature of the justification of democracy is correct in saying that I do not think that one should speak only of the intrinsic value of procedures. Democratic procedures and processes can and do have instrumental as well as intrinsic value, I think. And I try to make it clear how this can be so, though I don't think I have answered all the relevant questions on this issue.

The first and most important way in which I think instrumental value is essential to democracy is that it is essential to the basic justification of the state. I argue that the state is morally necessary in that it pursues morally urgent tasks such as the establishment of justice and basic security among persons. It also pursues public goods. If the state weren't instrumentally necessary to pursue these goods, then the argument for political democracy would be short circuited right from the start. Democracy, as I see it, is a decision making process that pursues these goods that treats persons as equals in ways they can see treats them as equals. Democracy, as I put it, realizes public equality among persons in the process of attempting to pursue these urgent moral goods.

The idea is that there is substantial disagreement among persons on questions as to what justice requires and how to pursue it and persons are highly falli- ble in their efforts to understand justice and the public good. They are highly cognitively biased in their understandings of justice and the common good because of their limited experience and limited capacities of inference. Hence the disagreement reflects conflict of interest. The interests in correcting for cognitive bias, in being at home in the world and in being recognized and affirmed as an equal provide the foundation, along with the facts of judgment, for the idea that persons rationally desire to live in a social world that they can see treats them as equals. And since there is significant disagreement on the values and substance of policy, democracy provides a basic way in which citizens can see that they are treated as equals even though policy and law do not always go their way and do not always treat them as equals as they see it. I argue that from a public standpoint there is intrinsic value to democracy because there is a basis of valuing democracy that is independent of the ends that people pursue in democracy. Those ends are controversial in significant part, and so cannot provide a public argument for democracy. But democracy can nevertheless be valued intrinsically as the appropriate egalitarian response to this disagreement and conflict.

Each citizen takes two standpoints on the democratic process. They attempt to use it to pursue what they take to be just and desirable outcomes but they also see that the process provides a public basis on which to treat each other as equals despite their differing goals. This conception of the intrinsic procedural value of democracy has nothing to do with what Rawls calls pure procedural justice since everyone has views about what the best outcomes of the process can be (though they have different views 
on these). And I don't think it has much to do David Estlund's ideas of fair proceduralism or fair deliberative proceduralism, which he mistakenly attributes to me (Estlund, 1998). In The Rule of the Many as well as in The Constitution of Equality, I argue very clearly that the purpose of the state is to realize justice and that the purpose of societal deliberation is to learn from each other and to improve our understandings of these matters that we are duty bound to pursue. The equality that democracy introduces is a kind of constraint on this process that publically realizes equality among citizens as they enter these processes.

I agree with Ivan Mladenović who, in the midst of his excellent account of the grounds and consequences of public equality, argues that I overstate the significance of publicity in my discussion (Mladenović, vide supra). He argues that one does not need to invoke public equality in the justification of institutions as well as interpersonal relations. He is right to say that public equality is especially important in the context of political and legal institutions and need not regulate interpersonal relations. The basic reason for this is that the publicity necessary in the context of a larger society is important for the relations among strangers who can be expected to know little about one another. In the relations among friends and family and maybe even colleagues, the more impersonal norms of public equality need not be as stringent. In these relations the mutual ignorance of interests and concerns does not obtain as strongly and so one can live by norms that imply a great deal more mutual knowledge. It should be said that these norms display a kind of publicity but not the kind that is necessary for society as a whole. As Mladeno- vic notes, friends and colleagues do share more refined understandings of each other's interests in terms of which they can justify their interactions. This is still a kind of publicity though on a smaller more local scale.

Mladenovic is also correct to take me to task for a certain sloppiness in my characterization of democracy as the unique realization of public equality in collective decision making (Mladenović, vide supra). I sometimes speak as if it is the unique realization of public equality simpliciter. I mean to say that when collectively binding decisions are to be made, democracy is the unique realization of public equality in the process of collective decision making in the context of pervasive disagreement and conflict. This accords with what he calls the first interpretation of my claim. Once we think of democracy and public equality in this way it is hard to see the merit in Richard Arneson's view that if we had an autocratic regime that brought about just outcomes, that would be sufficient to realize public equality (Arneson, 2004, p. 57). The problem is that the facts of pervasive disagreement and cognitive bias, which I assume are fully accepted by rational persons, would imply that the interests of those not included were not being taken into account. It would clearly imply that all person's interests were not being given equal consideration and that persons were not recognized and affirmed as equals. I would have thought that the same reply would work against Estlund's plural voting suggestion (Estlund, 2009: 245). The trouble is that the standards by which we choose who are the most competent are going to be partisan and the subjects of pervasive disagreement. Since the standards themselves could not be public (given disagreement) it would have to be the case 
that given the facts of disagreement and cognitive bias and fundamental interests in having one's judgment accorded respect when these facts obtain, persons would have very good reason for thinking that they were excluded or given less power on the grounds that their interests were of lesser significance.

Cerovac notes that an instrumental dimension comes in to the picture once we accept the Paretian egalitarianism that I defend (Cerovac, vide supra). He argues that my arguments against direct democracy, lottery democracy and in favor of democratic deliberation display a dimension of instrumentalism. His idea is that I argue against direct democracy and in favor of representative democracy on the grounds that representative democracy better pursues well-being than direct democracy does. The argument against lottery voting and in favor of democratic voting is also that democratic voting better secures wellbeing as does deliberation (Cerovac, vide supra). But this isn't quite the way I think of the argument for representative and deliberative democracy. The argument in favor of representative democracy is that it gives members of society a greater control over the society by means of having a much more effective way of making decisions. It is a Paretian egalitarian argument in that it argues that though direct democracy does seem to give greater equality in control over the society than does representative democracy, because the process of decision making is likely to be so ineffective since it makes no use of an intellectual division of labor, everyone gains in control over the society through representative democracy. Of course, a division of labor always threatens to realize a certain amount of inequality in power but even the power of the least powerful is likely to be greater than under direct democracy. So it is not so much well-being that is the prime mover in the argument, it is political power that is the very purpose of democracy to distribute equally. It is enhanced by representation. I think a similar argument can be run against non-deliberative views of democracy. Part of the egalitarian condition of democracy is that it tries to realize an equality in the cognitive conditions of political decision making. The idea is that open deliberation is a way to enhance these cognitive conditions throughout the society. The Paretian egalitarian idea that inequality of some good is more just than equality if everyone has more of the good in the unequal state now applies to the cognitive conditions.

One place where outcomes play a central and unqualified role in my account of democracy is when issues of the realization of public equality are at stake. I argue that democracy is a realization of public equality but I also argue that equal liberal rights are public realizations of equality as is a basic economic minimum for all. But this implies, I argue, that there is an internal limit to the authority of democracy in that a democratic decision that violate these requirements of public equality loses its authority. Here the idea is that public equality can provide an outcome standard for democracy in some cases. Democracy can be evaluated in terms of whether it protects public equality in the form of democracy or in the form of liberal rights or economic rights. Here the central argument for the intrinsic value of democracy comes up against a limit. The main argument is that democracy has intrinsic value because for many decisions there are no outcome standards that are public standards. But this is not true in the case of democratic, liberal or 
economic rights. They are public standards and so can be used to criticize democracy from the public standpoint. So here we can see that democracy can be intrinsically just when it comes to making decisions on which there is reasonable controversy but it can also be straightforwardly instrumentally valuable when it comes to decisions that concern matters at the core of public equality (Christiano, 2008, chap. 7). I have also argued since then that democracy does have great instrumental value in protecting certain basic rights of physical integrity (Christiano, 2011).

\section{Democracy and Public Reason}

Professor Baccarini's and Zelićs papers pose deep challenges to the approach to political philosophy that I have developed. In my book and some other articles I argue against a view of deliberative democracy that asserts that citizens must argue for law and policy on the basis of shared reasons and must abstain from arguing on the basis of reasons that are not shared even if they think that they are the correct reasons. I call this the narrow conception of deliberative democracy. I argue in favor of the wide conception of deliberative democracy that citizens may and ought to defend proposals on the basis of what they take to be the correct reasons whatever these are. My target in this discussion is Joshua Cohen's widely adopted conception of deliberative democracy (Cohen, 1993). I argue against this view that it is not required by any plausible conception of epistemic justification. I argue that it is not implied by any plausible conception of respect for the rational capacities of persons. I argue that it cannot avoid implying that a very demanding form of consensus is required by this approach, contrary to the avowed aims of the theorists who defend this view. And finally I argue that the view is not required by the demand that citizens treat each other as equals, indeed it threatens to introduce a form of invidious inequality.

The last two arguments go beyond criticism of Cohen's arguments to suggest deep problems in the ideal itself (Christiano, 2008, chap 5). The argument that the view requires an excessively demanding consensus is motivated by the following considerations. The Rawls and Cohen requirement of deliberative abstinence is grounded on the idea that it is more oppressive to persons when they live in a society regulated by some terms they do not accept than when they live in societies that do not conform to their ideas of justice (which may be controversial). For example, if I am committed to the ideas that people should be rewarded in accordance with their preinstitutionally defined deserts or that justice requires a certain kind of community and these are controversial, then by the requirement of deliberative abstinence I must be content to live in a society that ignores these principles. In other words I must be content to live in a society in which people do not receive their just deserts and I must respect the property of those who have more than they deserve while ignoring the fact that some have less than they deserve. The idea behind deliberative abstinence suggests that living in a society that implements these principles is worse for the person who rejects them than is living in a society that ignores these principles for the person who accepts them. But it is simply not clear what justifies this asymmetry. If there is symmetry between these two problems, then either we must give up on deliberative abstinence and reject the idea that these are really viola- 
tions or we must demand a much higher level of agreement on principles of justice than is compatible with the normal conditions of free political societies.

Nebojša Zelić questions whether a genuine symmetry arises in many cases. He invokes the case of stem cell research. The dispute arises because some think it is wrong to harvest stem cells from eggs that have been fertilized and then destroyed on the grounds that the fertilized eggs are persons. They think it is wrong to kill persons in order to improve the life chances of others. Others do not think of the fertilized eggs as persons and so see the conflict only between life and improved life chances of persons and so regard the trade off as acceptable (Zelić, ms 15). Zelić argues that there is no symmetry here because on the one side there are generally accepted reasons (improvement of life chances) while on the other side are reasons that are specific to a particular comprehensive doctrine. The latter impose something that they should not impose. But I think that this misconstrues the symmetry claim. My symmetry claim is that those who believe that persons are being murdered by this policy but who must nevertheless permit it to happen and contribute to a state that protects this activity are no less oppressed than someone who is required to stand by and watch people's life chances be diminished because some believe that stem cell harvesting is a kind of murder. The one must watch murder occur for the sake of a lesser good (because some don't think it is murder) while the other must stand by and watch people suffer because some think it is murder to do what is necessary to help them. The underlying motivation for the restriction to public reasons is the idea that it is oppressive to live by principles that one does not accept. I claim that this oppression can just as easily occur for someone who does believe in certain principles and watches the society violate them and who indeed must contribute to the institutions that do this.

Zelić argues against the symmetry in two ways as far as I can see. One, he says that the opponents of stem cell research cannot say that some other "narrow moral community won” (Zelić, vide supra) if stem cell research were performed while the proponents could say, I assume that the narrow religious community won if stem cell research was performed. Presumably this is because the purpose of the stem cell research is one that can be accepted on all sides, namely improving life chances, while the reason for stopping it, namely saving a fertilized egg because it is a person, is not accepted on all sides.

But this just seems to me to conceal the symmetry issue. It isn't at all clear that the opponents could not see their defeat as a result of a narrow moral community namely the community that does not think that fertilized eggs are persons. That is, after all, the original motivation for saying that one shouldn't stop the research. But the main point, in any case, is that the opponents must experience the society, of which they are a part and to which they contribute, as murdering persons if the research goes ahead, while the proponents must experience the society as one that does not properly care for persons if the research does not go through.

Zelić also argues that "It would be wrong to deprive people of some good or diminish certain political value on the basis of the belief that we cannot reasonably expect that these persons can accept" (Zelic, vide supra). Here the proposed asymmetry is that some people are losing a generally recognized good 
when the research is not done but no one is losing a generally recognized good when the research is done. But this is merely an affirmation of the public reason principle. The question I ask is, why is it wrong or problematic? And the answer I see in Rawls and Cohen is that it is oppressive to live with others on terms one does not accept. Once we put it in this way, the question of symmetry becomes is it oppressive to live in a society that refuses to accept the principles of justice one accepts and engages in many actions that violate those principles? Again, I don't see that there is an asymmetry here.

The second argument I give is that it is unclear how the deliberative abstinence advocated by Cohen is required by the idea of treating others as equal democratic citizens. I treat my fellow citizens as equals when I make sure that they have equal votes, resources for bargaining, opportunities to participate in deliberation and when I give them a respectful hearing when they present their views. The worry with the idea of deliberative abstinence is that it implies that one need not give another a respectful hearing when it challenges the commonsense morality of the society (to the extent that there is one). This looks like it has the potential for recommending that some people not be listened to and thus has the potential for implying that some are treated as less than equals.

Zelić questions whether I have given an adequate basis for community in my account of democratic deliberation (Zelic, vide supra). My intention with the idea of public equality is to give a kind of basis for community. Remember that public equality is meant to serve as a realization of the recognition and affirmation of each person as an equal, which I posit as a fundamental interest. Persons are duty bound to treat their fellows as equals and to affirm their equality and they are duty bound to try to define social life in a way that advances the interests of all of their fellows. The egalitarian pursuit of the common good is the fundamental idea here. But, of course, people have very different ways of conceiving of this more abstract idea and this will give rise to wide deliberation. I should add that I do not think that the account of equality in deliberation is merely distributional; my view is that one must listen to others in the process of deliberation and treat their views with respect. This involves a genuine attitudinal component. Two points are worth noting here about this. One, the kind of community I am proposing is somewhat thinner than the Rawlsian one; this is because I recognize the legitimacy of a much wider array of disagreements. I think this is truer to our experience of the modern state and society. Two, the value of community is grounded in deeper values. It is grounded in the values of human well-being and of equality. In this sense, I think of myself as giving a kind of relational conception of equality with the theory of public equality but grounding it in a deeper conception of the value of humanity and equality.

Professor Baccarini accepts that my arguments may be good ones against the version of deliberative democracy that Cohen advances. But he proposes instead an alternative view of the Rawlsian project that does not fall prey to the same problems. The alternative proposal is that the Rawlsian project is really concerned to establish the coherence of liberalism and that for this to be established one need only assume a highly idealized set of citizens who actually do agree on all the main ideas of justice and their specifications. The ideal of public reason 
here is that all citizens reason on the basis of shared reasons as in the view I have criticized but here the idea is that those shared reasons are "constitutive" of the ideals of freedom and equality and the idea of society as a fair system of cooperation (Baccarini, vide supra). In other words to argue in terms of any other reasons aside from these is to fail to treat one's fellow citizens as free and equal. In an ideal society we assume that everyone thinks in terms of these reasons because they all think in terms of treating each other as free and equal (Baccarini, vide supra). Thus the problem of asymmetry is avoided because we are assuming a kind of consensus on all the ideas of justice. And the problem of democratic equality is solved because there is agreement on these ideas and so no one is ignored in the process of deliberation. Hence the criticisms I direct at Cohen's project do not apply.

Baccarini suggests that this approach has a main advantage over the view I have defended. My view advances of picture of democratic society in which there is a great deal of disagreement about justice. It proposes to resolve the disagreement in an egalitarian way by giving persons equal political power in the process of collective decision making, and constraining collective decision making by giving persons equal liberal rights, an economic minimum and by altering the process of collective decision making in order to avoid, when necessary, the problem of persistent minorities. All of these ideas are grounds for institutional constraints on collective decision making. And when the constraints are violated, say when a group's freedom of expression is violated by a particular set of laws, those laws lose some of their democratic authority. All of this is supposed to be tied together by the idea, which I defend at length, that each of these constraints are realizations of public equality, the very same principle that grounds democracy in the first place. Hence, the activity of collective decision making is limited by appeal to the same principle that undergirds the justice of that collective decision making. Hence, I argue that there are internal limits to democratic authority.

In essence Baccarini's claim that the Rawlsian approach he favors is superior to mine comes down to the idea that my approach is not a particularly efficient way of protecting the freedom and equality of citizens and it is risky. This is because I do not impose a constraint on how citizens are to reason aside from the requirement that they reason in good faith on the basis of norms of the common good and justice. People are permitted to say whatever they think is right but if they land on an idea that violates public equality, they will not be able to achieve their aims through the democratic process. Baccarini thinks it is better if we envision a society in which people are not reasoning in terms of norms that violate freedom and equality. This provides a much better and cleaner guarantee of the liberties and democratic rights of citizens and of the protection of citizens from permanent minority status. If all citizens act and participate on the basis of the right conception of justice and of the right specification of that conception, what can go wrong?

It is not obvious to me that nothing can go wrong when citizens all act on the basis of the right conception of justice, properly specified. The familiar expression, "The road to hell is paved with good intentions," comes to mind here. For one thing, they may have the correct moral ideas but false empirical beliefs which may lead them to construct insti- 
tutions that curtail liberties in ways not envisioned. A simple example of this might be the case of sexual harassment. For a significant period of time it was not thought that free-wheeling discussion in the office of sexual activities could be intimidating and ultimately oppressive to the women. The women themselves may not have had a clear idea that this had a silencing and oppressive effect on them. It took a few decades to elaborate the conceptual framework of sexual harassment and some empirical understanding of its effects. To be sure, many of the people engaged in this activity were not particularly concerned with the freedom and equality of their female co-workers but I think we can imagine that a society of persons devoted to freedom and equality could fail to understand the effects of what we now call sexual harassment. Therefore, despite their devotion to the right reasons, they may still create an oppressive atmosphere for many of the women in the society undermining their abilities to act as free and equal participants. So there can be objective violations of the freedom and equality of persons even when persons act on the right conceptions of justice. The point of my view is that there are certain objective limits on what people may do to each other whether they are acting in good faith or not.

But my main issue with Baccarini's idea is that though this may well be a useful theoretical enterprise, it does not solve the problem that I think we need to solve when we are thinking of a just society. The problem is that there is pervasive disagreement on what justice is and on what the correct specifications of freedom and equality are. I take this to a problem that defines a main task of political philosophy. It is not very different from the problem Rawls described when he said that we need to devise a conception of justice for a society in which persons have fundamentally different conceptions of the good life. Here the idea is that we need to devise a conception of a just society in which persons have very different conceptions of justice. The specific question I pose is: how is it possible for persons to treat each other as equals despite a great diversity of views about the good life and about justice? And my solution is to give persons equal power to participate in collective decision making and equal liberal rights to participate in the creation of the more localized worlds they live in. When there is disagreement, let these persons work out how they live together on the bases of their own judgments against the background of equal power. The idea both determines the conditions under which they devise terms on which they live together and it defines certain limits to what they can decide since they must respect the underlying principles both in public and in private life.

There are two distinct things to be said about this process of respecting the disagreements. First, I am trying to develop a conception of what is involved in respecting others in the context of pervasive disagreement. That is the problem to be solved and it cannot be solved by either of the two Rawlsian ideas on offer because they both assume away the fundamental condition to be dealt with. But there is a second consideration here as well. This is the broadly Millian idea that the contest of ideas in political society can itself be a fruitful and highly desirable process even when the contest is between really bad ideas and better ideas (Mill, 1989, chap. 2). The idea is that this contest is a condition of progress in the development of our understanding of justice, the common good and our inter- 
ests. Again, the underlying assumption is that we are very limited in our abilities to grasp justice and that we have deep interests in being able to develop a better understanding of justice. This underlying assumption, which I think is deeply correct, is simply assumed away in the picture Baccarini proposes. To be sure, for all we know, he is right that the Rawlsian picture is the final word on justice in society. But I doubt this is correct: induction from reflection on the past assertions of certainty and the many substantive problems of the Rawlsian picture lead me to think that we can go a long way to improve our understanding of justice and that this will be in significant part enabled by the existence of a democratic and liberal society. To be sure, there is no guarantee we will arrive at a more just society and a better appreciation of justice; society has gone off the rails many times before. But I think our best hope is that we can make progress while treating each other as equals in a democratic and liberal society.

\section{Democracy and the Division of Labor in Political Societies}

Professor Prijic-Samarzija's essay is an excellent account of some of my efforts to find a reconciliation between the democratic ideal of free and equal citizenship and the need for an intellectual division of labor in the making of collective decisions. The history of western speculation in political philosophy starts with Plato's idea that democracy and the division of labor in political decision making are incompatible and that this works to the detriment of democracy since the division of labor is essential to political societies. I have made a number of efforts to solve this problem. The first effort in The Rule of the Many attempted to determine what kind of role citizens could play in an intellectual division of labor in collective decision making. The constraints I imposed on this pursuit were (1) that the role would be such that it would be compatible with citizens being essentially in the driver's seat in political decision making and (2) that the role does not assign them a task that would be overly demanding and incompatible with their work and family and other pursuits. My basic answer to this question was that if citizens determine the aims that a society is to pursue and the rest of the division of labor faithfully pursues those aims to the best of its ability, then the citizens are in the driver's seat. Of course the aims have to be reasonably determinate and citizens must decide on the trade-off schedules when there is conflict. These aims are concerned primarily with the basic values a society is to pursue and the constraints that a society must respect in the pursuit of various goals. The basic idea is that there is not the same kind of expertise in the case of the choice of aims because there is a great deal of disagreement on the basic set of values and their ordering. The idea of publicly acceptable moral expertise is not available in modern societies. This is not to say that individuals cannot recognize persons who may be superior in terms of the knowledge relevant to choice of aims, but only that there is no public standard. Citizens must choose who is most worthy of being listened to and they must choose this against a background of equal political power since any officially established unequal distribution would imply a public favoring of some persons' interests over others.

My thought was that as long as the rest of the division of labor faithfully pursued the aims of citizens, which 
would be chosen in some majoritarian way, the society would be democratic. Citizens could be in the driver's seat and they could be equals in this position. But I eventually turned to the problem of how the rest of the division of labor would have to be structured so as to realize this role of faithfully pursuing the aims of citizens. And here I developed the idea of a realistic system in which experts' and elites' activities would be concerned primarily with pursuing the aims of the citizens, a system which Professor Prijić-Samaržija describes well. It is meant to ensure that experts are devoted to pursuing the knowledge necessary to advance citizens' aims and are concerned to put it to the proper use. Organizations such as political parties and interest group associations can be designed with an eye to ensuring this, I argue, as long as the mechanisms of solidarity, overlapping knowledge, competition and sanctions are put to work in the right institutional configuration. I did argue here that citizens have an important role to play in the generation of this expert knowledge. If expert knowledge is genuinely to be focused on advancing the interests of citizens the development of it must in some way be responsive to the diversity of interests in the society (See Christiano, 2012).

But Professor Prijić-Samaržija points to a worry in my discussion to which I was not sufficiently alert before she showed it to me in the original version of her paper that she presented to me at the Summer School in Rijeka in June 2014. She points out that my discussion is exclusively concerned with establishing the objective reliability of the social system in producing knowledge that is capable of advancing citizens' aims (Prijić-Samaržija, vide supra). There is no intrinsic concern for the idea that citizens ought to in some way have a kind of rational confidence that their aims are being pursued as best they can. This seems to me now to be an unattractive picture of a democracy. The original picture is one in which citizens choose the aims and then have no knowledge of whether these aims are pursued or not. As long as they are pursued, my initial idea was that democracy is realized. But now Prijić-Samaržija has persuaded me that it is important that citizens have some kind of reasonable basis of confidence that the aims are being pursued and that there are some mechanisms that can tell them when they are not being adequately pursued. It is not enough that citizens choose the aims and the aims are being pursued, the citizens must have some reasonable confidence that this is so and citizens must be able to respond when that confidence has been undermined.

Initially I thought this kind of reasonable confidence would be hard to come by without imposing excessively demanding information requirements on citizens since it seemed they would have to have some of the knowledge experts have. That is why I resisted the idea that citizens must have reasonable confidence that the society is pursuing their aims. But Prijić-Samaržija points out that the very mechanisms I spell out that are meant objectively to ensure that the system is working can also give citizens reasonable confidence in the system. They can provide reliable low information shortcuts for citizens to see that the system is working to pursue their aims. The mechanisms of solidarity, overlapping knowledge, competition and sanctions can ensure that alarm bells go off when, for example, the science a political party relies on has become seriously deficient by the lights of the relevant intellectual community. Citizens do not have to have 
the relevant knowledge to know when the ideas no longer live up to the standards of the community. To be sure citizens are not in a position to evaluate a lot of the disagreements that occur among experts. But they will have a sense when the views are seriously deficient because the intellectual community has incentives to bring out the deficiencies. Hence citizens can have reasonable confidence that the expert opinion their legislators rely on is at least not seriously deficient to the extent that no alarm bells go off. I have developed these ideas in more detail in the article "Voter Ignorance Is Not Necessarily A Problem" (Christiano, 2015). ${ }^{1}$

Finally, I come to the paper by Ivanković. I find his discussion mostly quite persuasive and it is an especially relevant discussion for me because of my view that it is essential to think about democratic ideals in the context of the real institutional possibilities for realizing egalitarian ideals. My work in The Rule of the Many and in the later essay Ivanković discusses takes very seriously the idea that the ideals of democracy must be realizable in an institutional way. Furthermore, I think that our conception of democracy can be transformed by an understanding of how to realize it in institutional contexts. My own work so far has focused on the problem of low information rationality

1 There is a voluminous literature on information shortcuts and low information rationality in politics. Two of the seminal contributions are: Popkin, 1994 and Lupia and McCubbins, 1998. in the context of a division of labor and how democratic ideals can be made sense of in this context. Much empirical literature has focused on the necessity of shortcuts for citizens in this context (Christiano, 2015) and I have tried to integrate that into an understanding of democratic ideals.

I agree with Ivanković that an appreciation of cognitive bias and framing is essential to an understanding of democracy. Indeed, one of the cornerstones of my argument for democracy includes a conception of fundamental cognitive biases and the need to correct them. But I also agree that much more needs to be said about this. Two points can be noted. One, cognitive bias and framing are, as Ivanković says, features of everyday cognition that need to be taken account of in the making of legislation. I think the account of expertise can go some way to accommodating this concern. A second point is that framing and cognitive bias can, when not properly taken account of, threaten the heart of democratic decision making. This is particularly true when we are dealing with the kind of low information rationality that occurs in modern democratic societies. The need for shortcuts to cut information costs can easily be manipulated when citizens are not paying close attention. But it should be noted here that part of the point of large scale democratic deliberation is to find ways to reduce the opportunities of manipulation of citizens through an adversarial process. But these are points that need much greater elaboration and I thank Professor Ivanković for drawing my attention to these issues. 


\section{LITERATURE}

Arneson, R. (2004) Democracy is not Intrinsically Just, in: K. Dowding, R. E. Goodin and C. Pateman (eds.) Justice and Democracy: Essays for Brian Barry. Cambridge: Cambridge University Press.

Christiano, T. (1996) The Rule of the Many: Fundamental Issues in Democratic Theory. Boulder, CO: Westview Press.

Christiano, T. (2008) The Constitution of Equality: Democratic Authority and Its Limits. Oxford: Oxford University Press.

Christiano, T. (2011) An Instrumental Argument for a Human Right to Democracy. Philosophy and Public Affairs 39 (2): 142-176.

Christiano, T. (2012) Rational deliberation among experts and citizens, in: J. Mansbridge and J. Parkinson (eds.) The Deliberative System. Cambridge: Cambridge University Press.

Christiano, T. (2015) Voter Ignorance Is Not Necessarily A Problem. Critical Review: A Journal of Politics and Society 27 (3-4): 1-17.
Cohen, J (1993) Moral Pluralism and Political Consensus, in: D. Copp, J. Hampton and J. Roemer (eds.) The Idea of Democracy. Cambridge: Cambridge University Press.

Estlund, D. (1998) Beyond Fairness and Deliberation: The Epistemic Dimension of Democracy, in: J. Bohman and W. Rehg (eds.) Deliberative Democracy: Essays on Reason and Politics. Cambridge, MA: MIT Press.

Estlund, D. (2007) Democratic Authority: A Philosophical Essay. Princeton: Princeton University Press.

Estlund, D. (2009) On Christiano's The Constitution of Equality. Journal of Political Philosophy 17: 241-252.

Lupia, A., McCubbins, M. (1998) The Democratic Dilemma: Can Citizens Learn What They Need To Know? Cambridge: Cambridge University Press.

Mill, J. S. (1989) On Liberty. Cambridge: Cambridge University Press.

Popkin, S. (1994) The Reasoning Voter: Communication and Persuasion in Presidential Campaigns. Chicago: University of Chicago Press. 